\title{
Soilborne Wheat Mosaic Virus Movement Protein and RNA and Wheat Spindle Streak Mosaic Virus Coat Protein Accumulate Inside Resting Spores of Their Vector, Polymyxa graminis
}

\author{
Barbara A. Driskel, ${ }^{1}$ Phoebe Doss, ${ }^{2}$ Larry J. Littlefield, ${ }^{1}$ Nathan R. Walker, ${ }^{1}$ and Jeanmarie Verchot-Lubicz ${ }^{1}$ \\ ${ }^{1}$ Department of Entomology and Plant Pathology; and ${ }^{2}$ Electron Microscopy Facility, Oklahoma State University, Stillwater, \\ OK 74078 , U.S.A.
}

Submitted 4 December 2003. Accepted 2 February 2004.

\begin{abstract}
To study virus-vector interactions between Soilborne wheat mosaic virus (SBWMV) or Wheat spindle streak mosaic virus (WSSMV) and Polymyxa graminis Ledingham, $P$. graminis was propagated in plants grown hydroponically. $P$. graminis accumulated to high levels in several barley cultivars tested. Multiple developmental stages of $P$. graminis could be identified in infected barley roots. Accumulation of SBWMV and WSSMV inside $P$. graminis sporosori in the roots of soil-grown winter wheat and hydroponically grown barley was compared to determine if data obtained from plants naturally infected plants and plants infected by manual inoculation were similar. WSSMV coat protein (CP), SBWMV RNAs, SBWMV movement protein but not SBWMV CP were detected in both soil-grown winter wheat and hydroponically grown barley roots. These data are the first direct evidence that SBWMV and WSSMV are internalized by $P$. graminis.
\end{abstract}

Polymyxa graminis Ledingham is a biotrophic parasite of many cereals (Ledingham 1939), is distributed worldwide, and is a vector for plant viruses belonging to the genera $F u$ rovirus, Bymovirus, and Pecluvirus (Adams 1991; Brakke and Langenberg 1988; Ledingham 1939; Wiese 1987). In the United States, $P$. graminis is a vector for two viruses that cause significant yield losses in winter wheat, Soilborne wheat mosaic virus (SBWMV) and Wheat spindle streak mosaic virus (WSSMV) (Wiese 1987). In spite of the agronomic importance of $P$. graminis as a vector for viral diseases, United States isolates of $P$. graminis have not been routinely propagated for laboratory research.

It was shown previously that SBWMV is transmitted to plant roots by $P$. graminis zoospores (Rao 1968; Rao and Brakke 1969). Viruliferous zoospores were purified and used to inoculate healthy plant roots. Zoospores treated with alkali or detergents were also capable of transmitting virus to plant roots, suggesting that virus was internalized by the zoospores (Rao 1968; Rao and Brakke 1969). WSSMV is a bymovirus that is presumably transmitted by $P$. graminis. However, there have been no reports showing SBWMV or WSSMV virion particles inside $P$. graminis zoospores. In fact, the nature of SBWMV or WSSMV association with any $P$ graminis developmental stage has not been determined until now.

Corresponding author: J. Verchot-Lubicz; E-mail: verchot@okstate.edu
Previous studies of P. graminis developmental anatomy or studies exploring $P$. graminis transmission of plant viruses have relied on soil collected from fields known to contain a high population of $P$. graminis (Driskel et al. 2002; Langenberg and Giuchedi 1982; Littlefield et al. 1998; Verchot et al. 2001). Barley or wheat seeds are planted in pots of $P$. graminis-infested soil, and then, as plants are growing, infected roots can be collected for analysis. This method of inoculation has a number of drawbacks. First, roots can be easily damaged upon removal from the pots. Second, roots are often discolored by the soil, making them difficult to analyze microscopically. Third, the proportions of plants that become infected with $P$. graminis using this method vary significantly between experiments. Fourth, the time frame for harvesting roots to study $P$. graminis developmental anatomy is also variable. Zoosporangia have been observed as early as 12 days postplanting (dpp) and as late as $40 \mathrm{dpp}$ (Littlefield et al. 1998). Thus, in order to study $P$. graminis developmental anatomy or its ability to vector plant viruses, it is essential to develop a method to reproducibly propagate $P$. graminis in plant roots without using field soil.

A custom-built intermittent irrigation system was used to propagate a United Kingdom isolate of $P$. graminis in barley (Adams and Swaby 1988; Adams et al. 1986, 1988; Campbell 1988). In this study, we report a method for propagating an isolate of $P$. graminis in barley roots, using a commercially available ebb-and-flow hydroponic system. Initially, 11 barley cultivars were tested to identify a reliable experimental host of this isolate of $P$. graminis. $P$. graminis-infected roots were harvested from field-grown wheat plants and were used as inoculum for hydroponically grown barley plants. Previous attempts to inoculate hydroponically grown wheat with a similar inoculum were not successful (J. VerchotLubicz, unpublished data).

For comparison, field-grown winter wheat roots and hydroponically grown barley roots were embedded in LRWhite or paraffin and immunolabeling studies were conducted to detect SBWMV or WSSMV in $P$. graminis resting spores. Immunolabeling and in situ RNA hybridization studies revealed the presence of SBWMV movement protein (MP) and SBWMV RNA but not SBWMV coat protein $(\mathrm{CP})$ in $P$. graminis resting spores. WSSMV CP was also detected in resting spores. These data are the first evidence that these viruses are internally associated with $P$. graminis. 


\section{RESULTS}

Barley cultivars inoculated 3 dpp were highly susceptible to $P$. graminis.

Previous studies of $P$. graminis-SBWMV or $P$. graminisWSSMV interactions relied on plants grown in a field nursery or in pots using fungus-infested soil harvested from a field
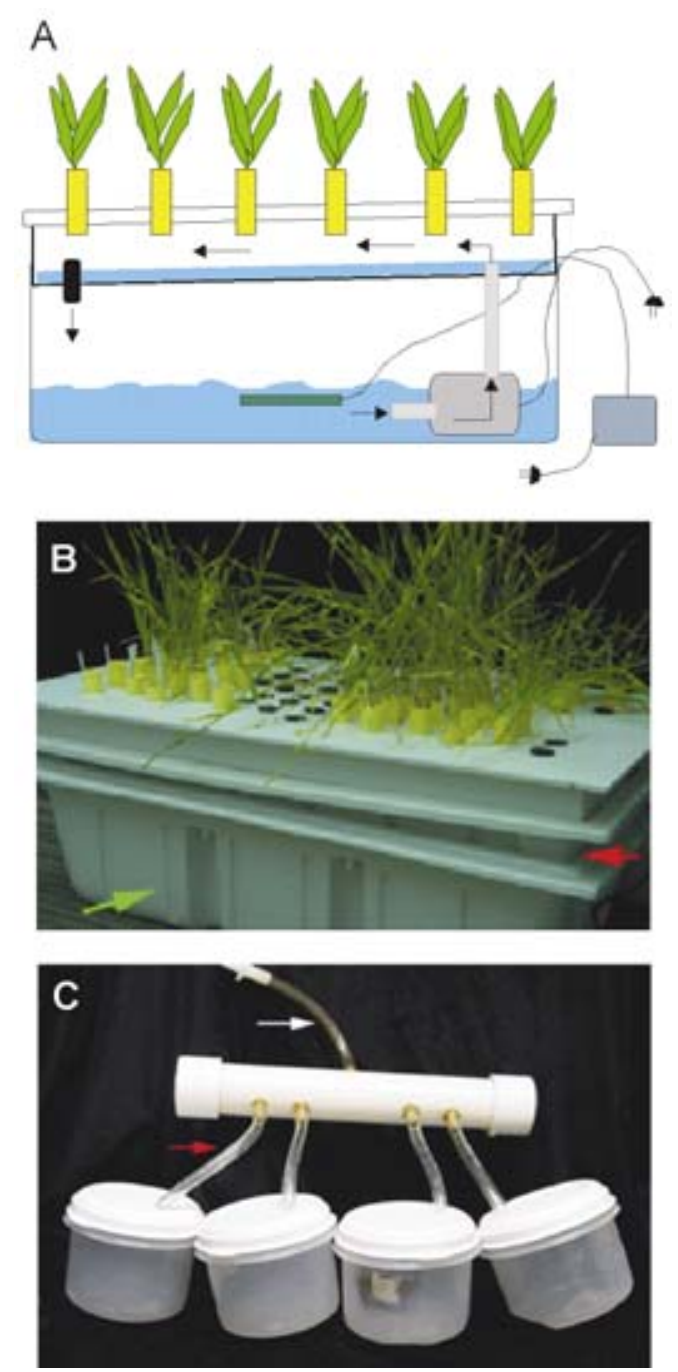

Fig. 1. Hydromax ebb-and-flow hydroponic system and root-washing system. A, Line drawing of the Hydromax hydroponic apparatus showing the holding tank (97.5-liter volume), upper reservoir tray and plant-holder tray containing barley plants grown in Cone-tainers (yellow). A submersible water pump (light gray square; flow rate of 560 liter/h) is timer-controlled and continuously fills the upper reservoir tray with nutrient solution for two periods of $6 \mathrm{~h}$ each day. Nutrient solution is pumped in the direction of the arrows from the holding tank to the upper reservoir tray and passes slowly back into the reservoir tank through a cylindrical drain (black) that has small pores located at its base. An air stone (green rectangle) was used to aerate the nutrient solution in the holding tank and is attached by a clear plastic tube to an external air pump (dark gray square; air output 1.5 liters/min). B, Image of the Hydromax ebb-and-flow system. The upper reservoir tray (red arrow) sits on top of the holding tank (green arrow) and is tilted at a slight angle away from the pump so nutrient solution flows toward the drain located at the opposite end of the tank. C, Custom-built root washing system consisting of four Rubbermaid containers for processing four different root mass samples. An inlet tube (white arrow) attaches to a faucet and to the PVC pipe. Four outlet tubes (red arrow) extend from the PVC pipe to the Rubbermaid containers. Water flows into and through the containers. A square hole is cut in the side of each container and wire mesh (black arrow) is glued over the hole. This allows water to drain out from the container while retaining the root mass inside. nursery (Driskel et al. 2002; Littlefield et al. 1998; Verchot et al. 2001). For this study, a commercially available ebb-andflow hydroponic system (Fig. 1A and B) was employed that allowed us to reproducibly propagate an isolate of viruliferous $P$. graminis in plant roots. Initial attempts to propagate this isolate of $P$. graminis in hydroponically grown winter wheat roots were unsuccessful (data not shown). However, we succeeded in propagating $P$. graminis in hydroponically grown barley roots. We found that hydroponically grown roots are easier to clean and have less damage than soil-grown roots, visualization of $P$. graminis in roots is easier, and $P$. graminis is abundant in hydroponically grown roots.

Experiments were first conducted to determine which barley cultivar or cultivars would be most reliable for propagating $P$. graminis, using a hydroponic cultivation system (Fig. 2 and Table 1). The susceptibilities of 11 barley cultivars to $P$. graminis were compared. Plants were inoculated at $3 \mathrm{dpp}$. Between 4 and 6 weeks postinoculation (wpi), plants were scored for the presence or absence of virus symptoms. Upper noninoculated barley leaves were collected and were analyzed by indirect enzyme-linked immunosorbent assay (ELISA) using monoclonal SBWMV antiserum (data not shown) (Driskel et al. 2002). Then, roots were harvested from plants that tested positive for SBWMV and were analyzed microscopically.

The occurrence of sporosori in plant roots was used as a measure of cultivar susceptibility to $P$. graminis. Mature sporosori are clusters of resting spores scattered in the cortex of barley or wheat roots, which are often pigmented, making them easy to identify microscopically (Littlefield et al. 1998). In longitudinal sections, multiple sporosori can often be detected in a single cell. Zoosporangia and plasmodia are less refringent than sporosori, and therefore, are not as easy to quantify.

$P$. graminis sporosori were detected in the roots of nine cultivars, of which eight cultivars accumulated greater than 100 sporosori per 1-cm root segment (Table 1). Between 80 and $100 \%$ of Harrington, Crystal, and B1202 plants contained greater than 100 sporosori per $1-\mathrm{cm}$ root segment (Table 1). Between 20 and $50 \%$ of Post 90, Bowman, Morex, Excel, and Black Hulless contained greater than 100 sporosori per $1-\mathrm{cm}$ root segment (Table 1). Although $60 \%$ of Stander plants were positive for $P$. graminis sporosori, an average of less than 20 sporosori per $1-\mathrm{cm}$ root segment was detected (Table 1 ). Neither Baronesse nor Robust accumulated P. graminis following inoculation at $3 \mathrm{dpp}$. Thus, Stander, Baronesse, and Robust were not effective hosts for $P$. graminis. The most reliable barley cultivars for hydroponic propagation of $P$. graminis were Harrington, Crystal, and B1202.

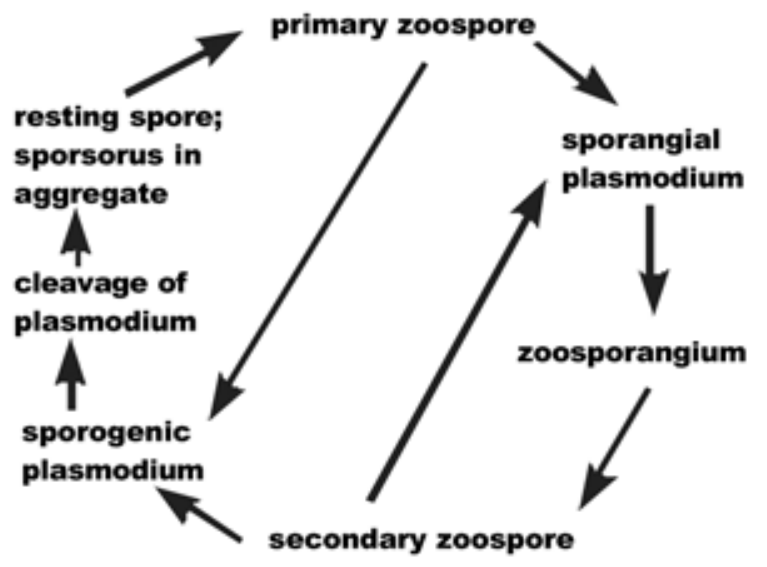

Fig. 2. Diagrammatic representation of the Polymyxa graminis life cycle (Karling 1968; Ledingham 1939; Littlefield 1998). 
P. graminis-infected roots of hydroponically grown barley (cv B1202) plants were used to inoculate two barley cultivars, B1202 and Morex. P. graminis sporosori were detected in $77 \%$ of B1202 roots (17/22) and in 100\% of Morex (5/5) roots (Table 2). All infected plants accumulated greater than 100 P. graminis sporosori per 1-cm root segment (Table 2), indicating that high infection levels were achieved using the B1202 inoculum.

\section{Microscopy of $\boldsymbol{P}$. graminis in barley roots.}

Barley (cv. B1202) roots were analyzed microscopically to determine if various life cycle stages of $P$. graminis could be observed in the roots of hydroponically grown plants. In roots harvested between 4 and 6 wpi, various stages of zoosporangial development, sporosori, as well as individual resting spores were detected (Figs. 2 and 3). Often, more than one stage was observed in a single root segment.

Zoosporangia were observed in root epidermal and cortical cells (Fig. 3A, B, and C). Zoosporangia were often tubular structures segmented by cross walls (Ledingham 1939). Exit tubes, which function for release of secondary zoospores into the environment, extended from zoosporangial thalli to the exterior of the cell (Fig. 3B). Sporogenic plasmodia appeared as lobed thalli (Fig. 3D). Sporogenic plasmodia cleave into segments, which give rise to resting spores (Ledingham, 1939). Resting spores within mature sporosori were most easily detected (Fig. 3E and F). The mature sporosori ranged in shape from spherical (Fig. 3F) to cylindrical (Fig. 3E) and contained many resting spores.

\section{SBWMV and WSSMV accumulate in $P$. graminis resting spores.}

Virus association with $P$. graminis resting spores was analyzed using wheat roots harvested at 6 months postplanting from a field nursery and barley roots harvested 6 wpi from plants that were grown hydroponically. Plants were harvested from the field and from the hydroponic system when virus symptoms first appeared in the leaves. Field-grown winter wheat is planted in September and symptoms do not appear until spring, while in the hydroponic system, infection occurs much faster. ELISA was used to confirm virus accumulation in wheat and barley leaves (data not shown).

Association of SBWMV in $P$. graminis resting spores was analyzed using immunofluorescence labeling and confocal microscopy. Wheat and barley root cross sections contained between 1 and 20 sporosori. More often multiple sporosori were

Table 1. Proportion of barley plants infected with Polymyxa graminis

\begin{tabular}{lcc}
\hline Barley cultivar & ${\text { Positive for } \text { P. }_{\text {graminis }} \mathbf{a}^{\mathbf{a}}}$ & Sporosori $\mathbf{c m}^{\mathbf{b}}$ \\
\hline B1202 & $5 / 5$ & $>100$ \\
Crystal & $5 / 5$ & $>100$ \\
Harrington & $4 / 5$ & $>100$ \\
Post 90 & $3 / 6$ & $>100$ \\
Morex & $2 / 5$ & $>100$ \\
Black Hulless & $1 / 5$ & $>100$ \\
Bowman & $1 / 5$ & $>100$ \\
Excel & $1 / 5$ & $>100$ \\
Baronesse & $0 / 5$ & - \\
Robust & $0 / 5$ & - \\
Stander & $3 / 5$ & $<20$ \\
\hline
\end{tabular}

${ }^{\text {a }}$ Root segments from five or six plants of each cultivar were observed for the presence of $P$. graminis sporosori. The ratio indicates number of plants positive for $P$. graminis relative to the total number of plants analyzed for each cultivar.

${ }^{\mathrm{b}}$ For each plant, root segments containing $P$. graminis sporosori were isolated, and the number of sporosori in six $1-\mathrm{cm}$ root segments was determined. The average number of sporosori observed in all analyzed $P$. graminis-infected segments is shown for each cultivar.

$c$ - indicates no sporosori were detected. detected in root epidermal, cortical, or endodermal cells. Cross sections of embedded wheat roots were analyzed, using either SBWMV CP or SBWMV MP antiserum. SBWMV MP but not $\mathrm{CP}$ was detected inside $P$. graminis resting spores (Table 3; Fig. 4C, D, and E). Similar patterns of protein accumulation were detected in soil-grown wheat and hydroponically grown barley plants, suggesting the culture method had no impact on the results. We viewed 17 wheat root cross sections and 50 barley root cross sections treated with SBWMV CP antiserum, and none were positive (Fig. 4E). However, 23 wheat root sections and 50 barley root sections were treated with SBWMV MP antiserum, and all were positive for viral MP (Fig. 4C and D). In wheat and barley root sections, fluorescence indicating accumulation of SBWMV MP was concentrated in the root cell walls and inside $P$. graminis resting spores. A similar pattern of SBWMV MP accumulation was reported previously in SBWMV-infected and SBWMV-MP transgenic wheat plants (An et al. 2003).

In barley root cross sections treated with buffer and secondary antiserum or a heterologous TMV antiserum, there was no fluorescence detected, indicating that nonspecific labeling of the tissue was minimal (Fig. 4F). Uninfected wheat and barley roots were also treated with SBWMV MP, SBWMV CP, and WSSMV CP antiserum, and nonspecific labeling was not detected (data not shown).

Nine wheat root cross sections were also analyzed using in situ hybridization to detect SBWMV RNA. Viral RNA was detected inside $P$. graminis resting spores (Fig. 5B). Viral RNA was detected in SBWMV-infected wheat roots that were positive controls (Fig. 5A). In sections treated with buffer and antiserum (no RNA probe), there was no label detected, indicating that nonspecific labeling did not occur (Fig. 5C). In situ RNA hybridization detected SBWMV RNA inside sporosori in field-grown wheat samples. Attempts to detect SBWMV RNA inside $P$. graminis resting spores in

Table 2. Proportion of barley plants infected with Polymyxa graminis following inoculation with hydroponically grown root inoculum ${ }^{\mathrm{a}}$

\begin{tabular}{lcc}
\hline Cultivar & Proportion infected plants $^{\mathbf{b}}$ & Sporosori/cm $^{\mathbf{c}}$ \\
\hline $\mathrm{B} 1202$ & $17 / 22$ & $>100$ \\
Morex & $5 / 5$ & $>100$ \\
\hline
\end{tabular}

${ }^{a}$ Plants were inoculated 3 days postplanting. Root segments from plants of each cultivar were observed for the presence of $P$. graminis sporosori.

${ }^{\mathrm{b}}$ The ratio indicates the number of plants positive for $P$. graminis relative to the total number of plants analyzed for each cultivar.

${ }^{c}$ Sporosori were counted in $1-\mathrm{cm}$ root segments. The average number of sporosori in six segments per plant is reported.

Table 3. Sections of Polymyxa graminis wheat and barley roots positive for SBWMV or WSSMV

\begin{tabular}{lcc}
\hline Antiserum & Wheat roots & Barley roots \\
\hline SBWMV CP & $0 / 17$ & $0 / 50$ \\
SBWMV MP & $23 / 23$ & $50 / 50$ \\
SBMWV RNA & $9 / 9$ & $\mathrm{ND}^{\mathrm{b}}$ \\
WSSMV CP & $\mathrm{ND}$ & $4 / 7^{\mathrm{c}}$ \\
Buffer & $0 / 21$ & $0 / 50$ \\
TMV CP & $0 / 22$ & $0 / 50$ \\
\hline
\end{tabular}

${ }^{\text {a }}$ Four blocks from separate root masses that contained $P$. graminis in cross sections were sectioned and probed using antiserum to Soilborne wheat mosaic virus (SBWMV) coat protein (CP), SBWMV movement protein (MP), Wheat spindle streak mosaic virus (WSSMV) CP, Tobacco mosaic virus (TMV) $\mathrm{CP}$, or were probed by in situ hybridization to detect SBWMV RNA.

${ }^{\mathrm{b}} \mathrm{ND}=$ not determined.

c Sections taken from two blocks were positive for WSSMV and SBWMV.

${ }^{\mathrm{d}}$ Sections were treated with buffer and secondary antiserum. 
barley roots were unsuccessful. The six-week-old barley roots, which were known to contain $P$. graminis sporosori, were smaller and more fragile than the six-month-old wheat roots. While we could obtain intact sections of paraffin-embedded wheat roots for in situ hybridization analyses, we could not easily obtain intact sections of barley roots embedded in paraffin. Thus, an alternative method needs to be developed to conduct in situ RNA hybridization using small barley roots. Both wheat and barley roots were easily embedded in LR-White, and immunolabeling studies to detect viral proteins could be conducted in both tissues.

Samples taken from one barley plant were positive for SBWMV and WSSMV. Seven sections taken from four blocks were treated with WSSMV CP antiserum, and four sections contained sporosori that were positive for WSSMV CP (Table 1; Fig. 6). These sections contained at least three sporosori per section, and in each section, all sporosori were positive for WSSMV and SBWMV.

\section{DISCUSSION}

In this study, we report a method for propagating an isolate of $P$. graminis in barley roots, using a commercially available ebb-and-flow hydroponic system. Using this propagation system, experiments were conducted to identify a reliable experimental host of this isolate of $P$. graminis. Eleven barley cultivars were tested for their susceptibility to $P$. graminis, and we selected one highly susceptible cultivar, B1202, for the remaining studies exploring virus-vector interactions. There were significant differences among these 11 barley cultivars in their susceptibility to $P$. graminis. Between 50 and $100 \%$ of B1202, Crystal, Harrington, and Post 90 plants were infected with $P$. graminis, while the proportions of Morex, Black Hulless, Robust, Stander, Bowman, and Excel plants infected with P. graminis (Table 1) were between 0 and $40 \%$. The differences in cultivar susceptibility might be due to genetic differences affecting their predisposition to infection by $P$. graminis (it is not known if any of the cultivars are resistant to $P$. graminis). Alternatively, quality of the inocula was a factor determining the extent of $P$. graminis infection obtained in some cultivars. Inocula derived from field-grown wheat plants contained nematodes, fungi, and bacteria that could attach to the root surface and were potentially antagonistic to $P$. graminis infection.

SBWMV is transmitted by $P$. graminis zoospores to plant roots. Its association with $P$. graminis resting spores and zoospores is impervious to acid, alkali, or detergent treatments and has led others to suggest the virus is inside the vector (Rao and Brakke 1969). Electron microscopy has been used to show virus is present in a macerated root inoculum, but no one has yet reported SBWMV virion particles inside $P$. graminis zoospores or resting spores (Rao and Brakke 1969).

The presence of SBWMV MP and RNA inside $P$. graminis resting spores suggests that SBWMV may be intimately associated with the fungus not as virion particles but as an alternative form. One possibility is that SBWMV is able to replicate inside $P$. graminis. The occurrence of viral RNA and MP in sporosori might indicate replication and translation of viral RNAs. Since SBWMV MP is expressed from a subgenomic RNA, MP expression would require production of minus strand RNAs and subsequent transcription of subgenomic RNAs. Thus far, we have not detected minus strand RNAs by in situ RNA hybridization (data not shown). Other methods to detect minus strand RNAs need to be explored. Since we lack antiserum to other SBWMV proteins
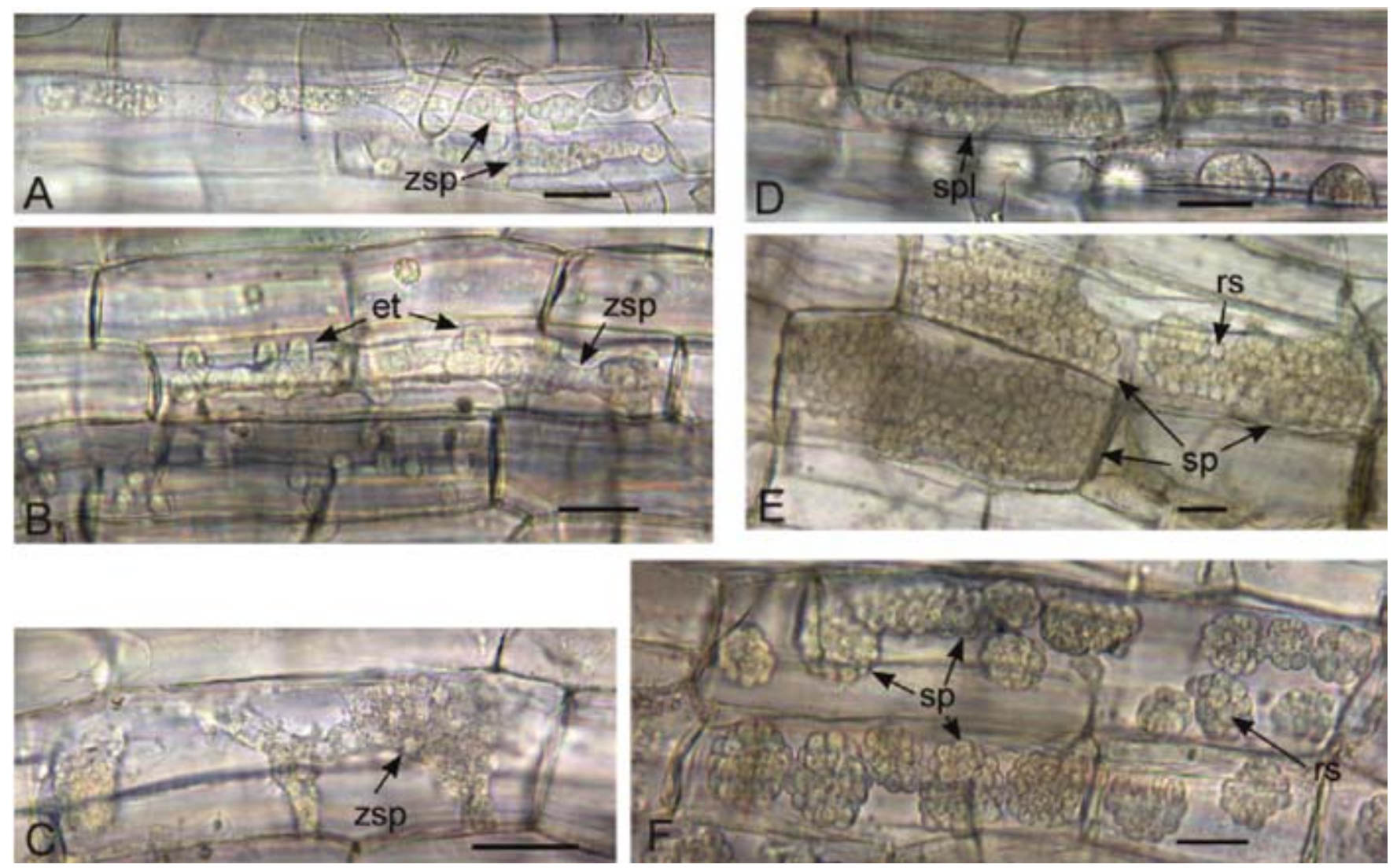

Fig. 3. Images of Polymyxa graminis in roots. A, B, and C, P. graminis zoosporangia (zsp). Some zoosporangial exit tubes (et) are indicated and function for release of zoospores to the extracellular environment. D, P. graminis sporogenic plasmodium (spl) in root cells $\mathbf{E}$, and $\mathbf{F}$, . graminis sporosori (sp). Some individual resting spores (rs) are indicated. Bars $=100 \mu \mathrm{m}$. 
(such as replicase or the $19 \mathrm{~K}$ proteins), further experiments to determine if other viral proteins are translated inside $P$. graminis were not conducted.

Another possibility is that $P$. graminis might not transmit SBWMV virion particles but might transmit a ribonucleoprotein complex consisting of SBWMV MP and RNA to host cells. Evidence of SBWMV MP and RNA inside resting spores suggests that there might be such a ribonucleoprotein complex. Viral ribonucleoprotein complexes have been described in relation to virus cell-to-cell and vascular transport. Viral MPs, related to the ' $30 \mathrm{~K}$ superfamily' of viral MPs, mediate viral cellto-cell and vascular transport by binding viral nucleic acids and carrying them through plasmodesmata and through the vasculature (Melcher 2000). The SBWMV MP is related to the $30 \mathrm{~K}$ superfamily and might function in this manner (An et al. 2003; Melcher 2000).

Based on the data presented in this study, we propose a new model for $P$. graminis transmission of SBWMV (Fig 7). Mature resting spores contain a ribonucleoprotein complex consisting of SBWMV MP and viral RNA. Primary zoospores, released from mature resting spores, also contain the SBWMV MP-RNA complex internally. Primary zoospores penetrate adjacent cells and zoosporangial thalli develop. The zoosporangium is a source of secondary zoospores that are released through exit
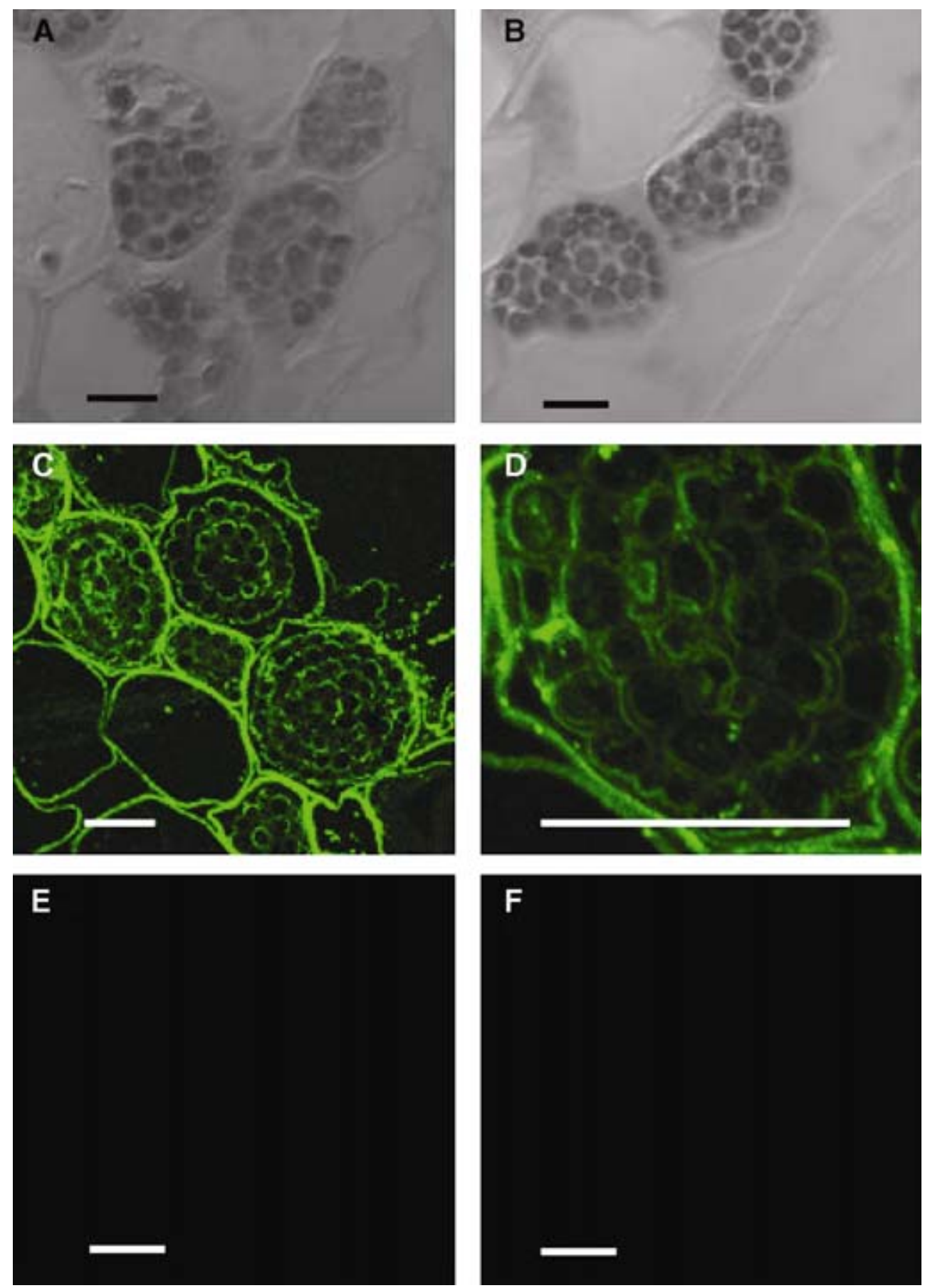

Fig. 4. Immunofluorescence labeling of movement protein in cross sections of barley roots. A, and $\mathbf{B}$, Images taken using the transmitted light detector of the confocal microscope showing cross sections of sporosori in root cortical cells. C, and D, Images taken of sporosori that were labeled with Soilborne wheat mosaic virus (SBWMV) movement protein antiserum. E, Image of sporosori treated with SBWMV coat protein antiserum show no labeling. F, Image of sporosori treated with Tobacco mosaic virus antiserum. Bar $=20 \mu \mathrm{m}$. 
tubes into adjacent cells. SBWMV MP-RNA complexes are also associated with zoosporangia and are released into adjacent cells along with secondary zoospores (Fig. 7).

Transport of SBWMV from the fungus into the plant host as a complex of SBWMV MP and RNA has some important advantages. First, when virus is released into the adjacent cell, it has to compete with the fungus for physical space to replicate and accumulate. The fungus takes over much of the cell, and there may be little physical room for the virus to accumulate. Virus and fungus might compete for cellular resources to promote their own life cycles. To avoid competition, SBWMV might first move out of the primary infected cell into adjacent cells (where the fungus does not reside) and initiate its life cycle in those cells. In that case, SBWMV MP is essential to mediate SBWMV cell-to-cell movement. Second, if the host cell launches a defense response against $P$. graminis, then movement of SBWMV out of the cell could aid in its own survival. The ability of SBWMV to survive and spread in the host plant might require the SBWMV MP to mediate viral plasmodesmata transport as a first step in SBWMV infection.

This study also presents the first evidence that WSSMV accumulates inside $P$. graminis resting spores. Unlike SBWMV $\mathrm{CP}$, WSSMV CP was found in some of the P. graminis sporosori examined in infected barley roots. WSSMV was not detected in wheat roots and was detected only in some barley roots. Since the inoculum used was not a single-spore isolate of $P$. graminis but was a mixed population of $P$. graminis and other microbes, some plants contained both viruses and others contained only SBWMV.

WSSMV is a bymovirus and is not related to SBWMV, although both viruses often are detected in the same host plant and might cause a synergistic disease (Kendall and Lommel 1988). The mechanism for transmission of WSSMV may be unrelated to SBWMV. Further research is needed to characterize the mechanism for WSSMV transmission.

\section{In situ labeling SBWMV-infected wheat roots}

\section{In situ labeling SBWMV in P. graminis resting spores}

\section{SBWMV-infected wheat roots treated with buffer (no probe)}

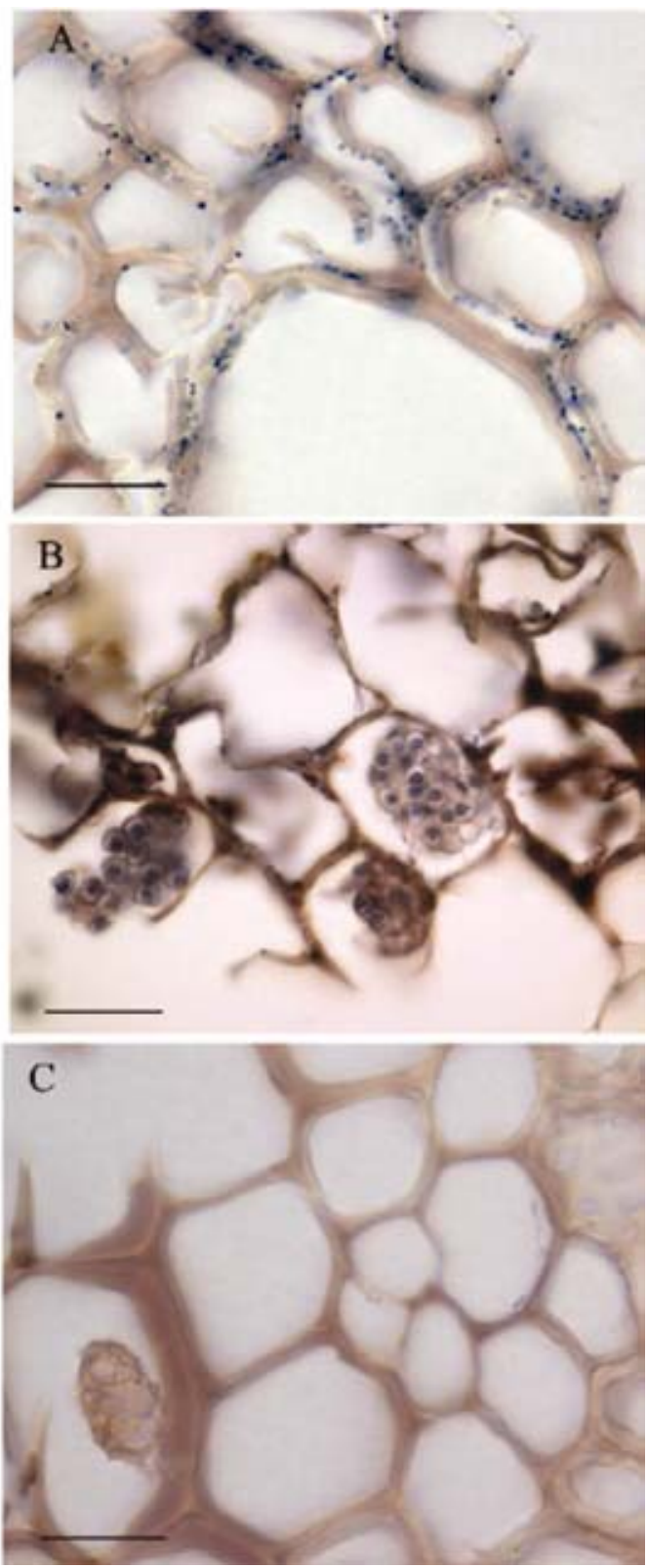

Fig. 5. In situ RNA hybridization of Soilborne wheat mosaic virus (SBWMV)-infected wheat roots and viruliferous Polymyxa graminis sporosori. An RNA probe was used to detect SBWMV RNA. A, and B, Purple spots in wheat root cross sections and in sporosori cross sections indicate presence of SBWMV RNA. C, No purple spots were detected in samples treated with buffer and no RNA probe. Arrows in B and C indicate sporosori. Bars $=30 \mu \mathrm{m}$. 


\section{MATERIALS AND METHODS}

\section{Plant material and the hydroponic system used}

\section{for plant propagation.}

Roots from hard red winter wheat plants (Triticum aestivum L. cv. Vona) infected naturally with SBWMV were obtained from a field nursery located near the Oklahoma State University campus. This nursery has been used for more than 20 years to screen wheat breeder material for reaction to SBWMV and $P$. graminis. Winter wheat is planted in September and then irrigated heavily for approximately five days just as coleoptiles are emerging through the soil. This protocol facilitates infection of seedling roots by $P$. graminis, and results in consistent and severe infection of wheat that is susceptible to SBWMV.

Ten cultivars of spring barley were propagated hydroponically: B1202, Baronesse, Black Hulless, Bowman, Crystal,
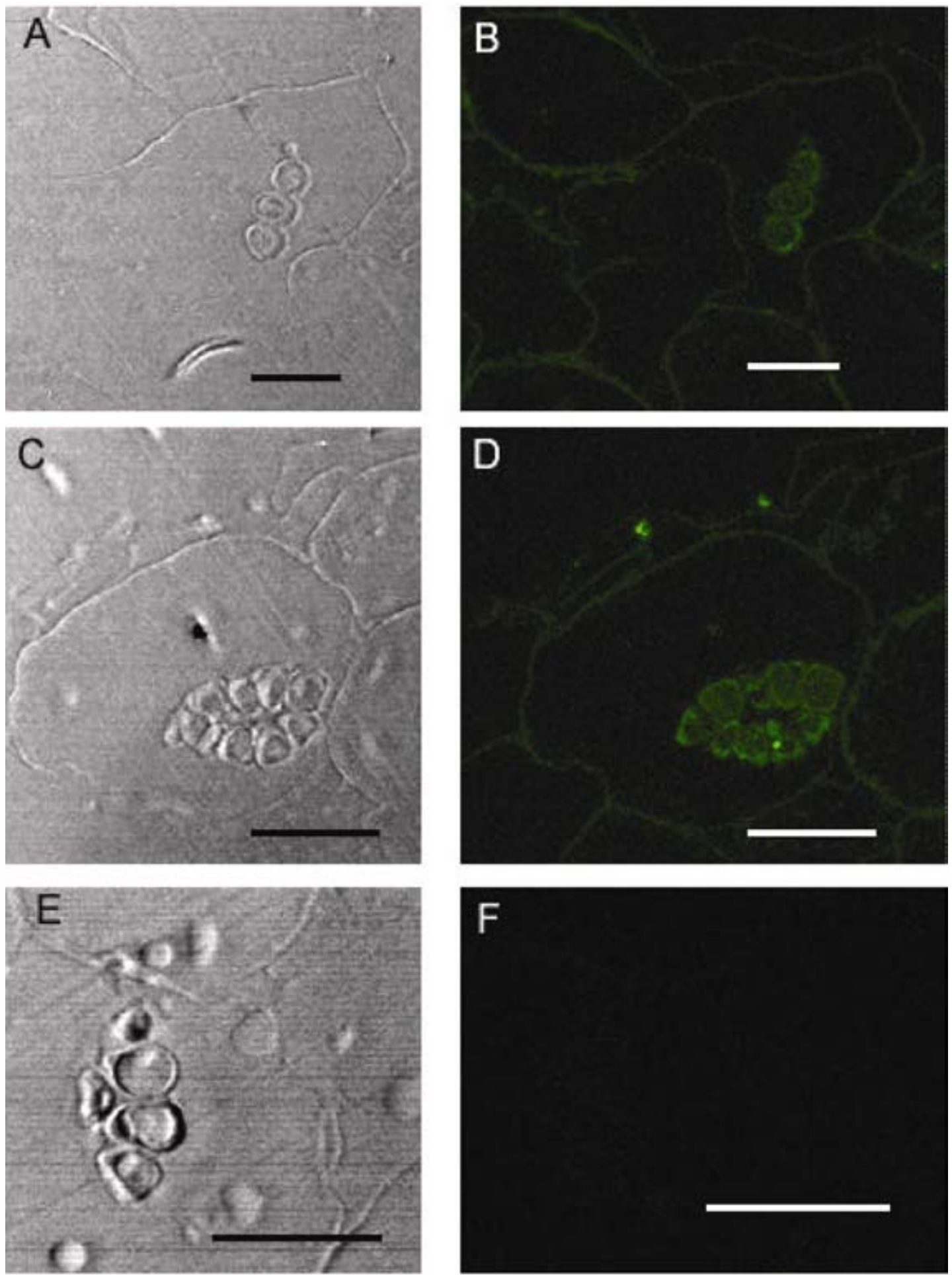

Fig. 6. Immunofluorescence labeling of Wheat spindle streak mosaic virus (WSSMV) coat protein (CP) in cross sections of barley roots. A, B, C, and D, Transmitted light and fluorescence images of resting spores or sporosori in root cortical cells. A and C show sporosori that were labeled with WSSMV CP antiserum (B and D, respectively). E, Resting spores F, treated with buffer and secondary antiserum. Bar $=20 \mu \mathrm{m}$. A, C, and $\mathbf{E}$, Transmitted light images of resting spores or sporosori in root cortical cells. B, and D, WSSMV CP was detected in resting spores by immunofluorescence labeling. Sections in A and B, $\mathrm{C}$ and $\mathrm{D}$, and $\mathrm{E}$ and $\mathrm{F}$ are the same, but images were taken using either the transmitted light detector or a $\mathrm{Kr} / \mathrm{Arg}$ laser. 
Excel, Harrington, Morex, Robust, and Stander. One cultivar of winter barley (Post 90) was also propagated hydroponically. Plants of each cultivar were grown in sterile quartz silica sand (Unimin Corp., Guion, AR, U.S.A.) in UV-stabilized, 16.4-cm Cone-tainers (Ray Leach Cone-tainers; Hummert International, Earth City, MO, U.S.A.). The conical bottom of each Cone-tainer was cut off and covered with $100-\mu \mathrm{m}$ mesh nylon membrane (Spectra/Mesh, Fisher Scientific, Pittsburgh, PA, U.S.A.). The membrane was held in place using waterproof tape. Plants were harvested between 4 and 6 wpi. Spring cultivars were generally taller (Feekes scale of 8 or 9) than the winter cultivars (Feekes scale of 6 or 7) at the time of harvest.

Modified Cone-tainers were placed in a Hydromax ebb-andflow hydroponic system (Foothill Hydroponics, North Hollywood, CA, U.S.A.) (Fig. 1A and B). The hydroponic system includes a plant-holder tray, which originally lay on top of the upper reservoir tray. The original plant-holder tray was substituted with a $53.5 \times 90.5 \times 0.5 \mathrm{~cm}$ sheet of PVC plastic, with 80 holes $(2.5-\mathrm{cm}$ diameter) drilled into the surface to accommodate the modified Cone-tainers (Fig. 1B). Four 4.8-cmwide support strips made of 0.5 -cm-thick PVC plastic were glued together with PVC pipe adhesive to form a rectangular box (dimensions $47 \times 84 \mathrm{~cm}$ ) and then were slotted into a 0.5 $\mathrm{cm}$-wide groove cut into the underside of the plant-holder tray.

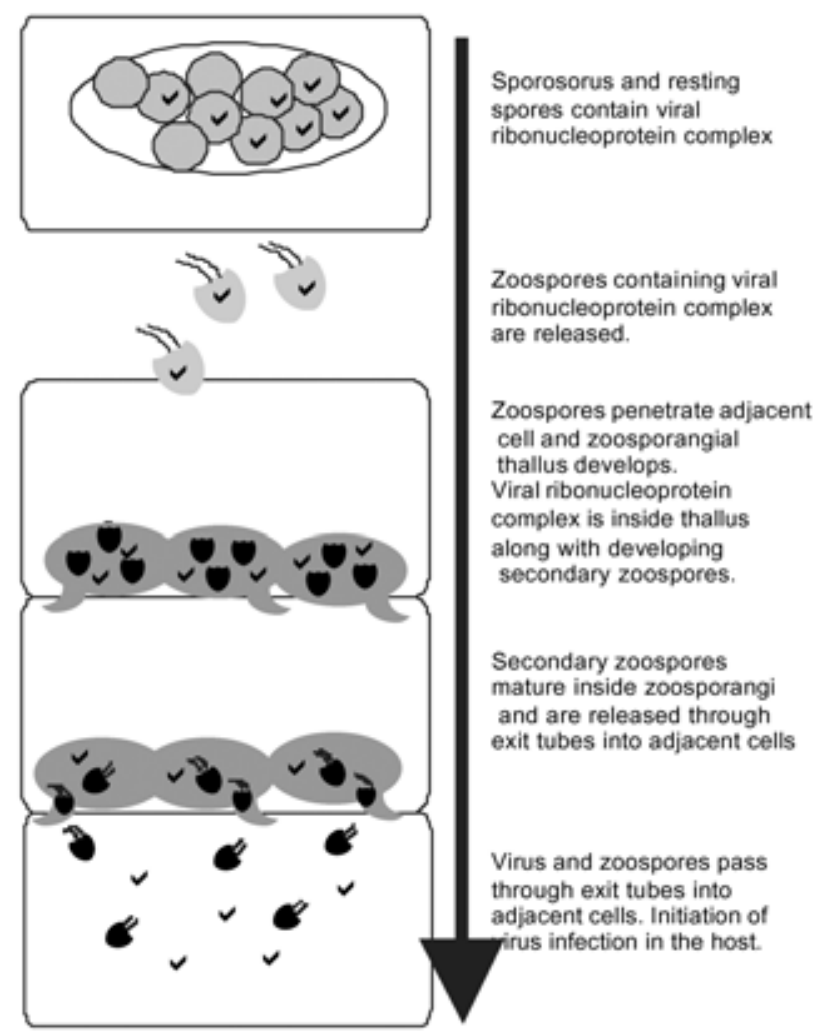

Fig. 7. Proposed model for Polymyxa graminis transmission of Soilborne wheat mosaic virus (SBWMV). Viral movement protein (MP) and RNA might form a ribonucleoprotein complex inside resting spores. Cell at the top of the model depicts a sporosorus and resting spores (gray spheres) containing SBWMV ribonucleoprotein complexes (black lines). Resting spores mature and flagellate zoospores are released into extracellular spaces. Previous studies suggest virus is internalized by zoospores (Rao and Brakke 1969). Zoospores attach to cell surface and penetrate cells. Zoosporangial thalli forms inside adjacent cells. Zoosporangium (dark gray lobes) contains SBWMV ribonucleoprotein complex and immature secondary zoospores (black hemispheres inside zoosporangium) form. Zoosporangium releases mature secondary zoospores through exit tubes into adjacent cells. SBWMV ribonucleoprotein complex is released along with secondary zoospores into adjacent cells and virus infection of the host is initiated.
The new plant-holder tray looks like a box lid (Fig. 1B). A central brace $(45 \times 4.8 \times 0.5 \mathrm{~cm})$ was glued across the width on the underside of the plant-holder tray for added support.

Nutrient solution (40 liters; $2.5 \mathrm{mM} \mathrm{KNO}_{3}, 1.0 \mathrm{mM}$ $\mathrm{KH}_{2} \mathrm{PO}_{4}, 1.0 \mathrm{mM} \mathrm{NaNO}, 0.75 \mathrm{mM} \mathrm{Ca}\left[\mathrm{NO}_{3}\right]_{2}, 0.75 \mathrm{mM}$ $\mathrm{MgSO}_{4}, 1.0 \mathrm{mM} \mathrm{FeSO}, 0.1 \mathrm{ppm} \mathrm{MnCl}_{2}, 0.05$ ppm $\mathrm{H}_{3} \mathrm{BO}_{3}$, $0.025 \mathrm{ppm} \mathrm{ZnSO}_{4}, 0.005 \mathrm{ppm} \mathrm{CuSO}_{4}$, and $0.005 \mathrm{ppm}$ $\left.\left[\mathrm{NH}_{4}\right]_{2} \mathrm{MoO}_{4}\right)($ Adams 1986) were added to the holding tank. The hydroponic system was maintained in a controlled environmental chamber at 15 to $18^{\circ} \mathrm{C}$, with a minimum photoperiod of $12 \mathrm{~h}$, as recommended by Adams and associates (1986). The nutrient solution was changed weekly.

\section{Preparation of inoculum and root washing system.}

Initially, $P$. graminis-infected roots were obtained in September 2001 from winter wheat (cv. Vona) grown in an Oklahoma State University SBWMV field nursery. The soil in this nursery is known to contain high populations of $P$. graminis and SBWMV (Driskel et al. 2002; Verchot et al. 2001). Plants showing symptoms of SBWMV were collected and ELISA analyses were conducted to verify that the plants were SBWMV-infected (data not shown). Roots of P. graminisinfected, hydroponically grown, barley (cv. B1202) plants were also used as inoculum to determine if $P$. graminis could be transmitted between hydroponically grown plants. To prepare inocula, roots of hydroponically grown plants were harvested between 4 and 6 wpi.

A root washing system (Fig. 1C) was constructed to clean plant roots for microscopic analysis. The root washing apparatus was constructed using a 30-cm-long, 3.75-cm-diameter schedule 40 PVC pipe that had plastic caps glued to each end as closures. Five, $15-\mathrm{cm}$-long pieces of plastic tubing $(0.625$ $\mathrm{cm}$ in diameter) were attached to the single inlet brass connection and the four brass outlet connections (Fig. 1C). The plastic inlet tube was connected to a distilled water faucet, and the four outlet tubes channeled water into separate 700-ml Rubbermaid containers that served as "root-washing containers" (Fig. 1C). A square hole was cut into the side of each Rubbermaid container, and a stainless steel screen $(0.125-\mathrm{cm}$ pore size) was glued over the hole, using epoxy resin (Fig. 1C).

Wheat and barley root masses were cut at the base of the stem, most of the sand or dirt was shaken off, and the root masses were divided in half longitudinally. Each barley root mass was added to separate root-washing containers for cleansing, and four root masses could be simultaneously washed (Fig. 1C). Root masses were washed vigorously for $1 \mathrm{~h}$ with running distilled water, to remove sand, dirt, and micro fauna. Water flowed into each container through outlet tubes and then flowed out of each container through the screen. Roots were dried on paper for 1 week in a greenhouse and were stored at room temperature in a desiccator with desiccant.

Approximately $5 \mathrm{~g}$ of dried roots (either derived from fieldgrown or hydroponically grown plants) were cut with scissors into segments $(<1 \mathrm{~cm}$ in length). Roots were then ground using a mortar and pestle. Prior to grinding with a pestle, a wire screen was used to line the inside of the mortar. The screen was essential to produce a fine root powder when grinding with the pestle. Approximately $300 \mathrm{ml}$ of cold 10 $\mathrm{mM}$ Na-phosphate buffer ( $\mathrm{pH}$ 7.0) was then added to the powdered inoculum and mixed thoroughly. Plants were inoculated at $3 \mathrm{dpp}$. liquid inoculum $(3 \mathrm{ml})$ was added to the surface of the sand in each Cone-tainer.

\section{Embedding plant material in Paraplast or LR-White.}

Root segments were taken from six-month-old (Feekes scale 6 to 7) symptomatic, field-grown, hard red winter wheat plants (cv. Vona) and four- to six-week-old hydroponically grown 
barley (cv. B1202) and were embedded either in Paraplast (Electron Microscopy Sciences, Fort Washington, PA, U.S.A.) or LR-White resin (Ted Pella, Inc., Redding, CA, U.S.A.). SBWMV-infected plants were identified by ELISA of leaf extracts with SBWMV antiserum (data not shown). Root segments were collected within approximately $4 \mathrm{~cm}$ of the soil surface (Verchot et al. 2001) and were embedded.

For in situ hybridization studies, segments of field-grown wheat roots were embedded in Paraplast (Berlyn and Miksche 1976; Verchot et al. 2001). Samples were placed in fixative (10:2:1 dilution of ethanol, formaldehyde, and acetic acid) overnight at $4{ }^{\circ} \mathrm{C}$ and then dehydrated in a graded series of 50,60 , $70,85,95$, and $100 \%$ ethanol. Ethanol was replaced with a graded series of 25, 50, 75, and $100 \%$ xylene. Paraplast (Electron Microscopy Sciences) chips were added to the samples at room temperature, and samples were incubated overnight. Samples were infiltrated with Paraplast at $62^{\circ} \mathrm{C}$ for 3 days, and molten Paraplast was changed twice each day. Samples were transferred to plastic molds filled with molten Paraplast and were allowed to harden for $2 \mathrm{~h}$ in cool water (Verchot et al. 2001).

For immunofluorescence labeling studies, root segments were embedded in LR-White resin (Ted Pella, Inc.) as described previously (Littlefield et al. 1998). Root segments were fixed for $2 \mathrm{~h}$ at room temperature under vacuum in a solution containing $0.5 \%$ glutaraldehyde, $4.0 \%$ paraformaldehyde, and $100 \mathrm{mM}$ sucrose in $50 \mathrm{mM}$ sodium cacodylate buffer ( $\mathrm{pH}$ 7.2). The samples were rinsed in $50 \mathrm{mM}$ cacodylate buffer (without sucrose) and then postfixed in aqueous $1 \%$ osmium tetroxide for $1 \mathrm{~h}$ at room temperature. Samples were rinsed in water, were dehydrated in a graded series of water and ethanol, and then were infiltrated and embedded in LRWhite resin. Samples were cut with a ultramicrotome $(1 \mu \mathrm{m})$ and affixed on ProbeOn Plus slides (Fisher Biotechnology, Pittsburgh, PA, U.S.A.).

\section{Immunofluorescence labeling for confocal microscopy.}

Slides were incubated in blocking solution (50 mM Tris$\mathrm{HCl}, \mathrm{pH} 7.4,150 \mathrm{mM} \mathrm{NaCl}, 2 \%$ bovine serum albumin (BSA) fraction $\mathrm{V}$ ) for $1 \mathrm{~h}$ at $4{ }^{\circ} \mathrm{C}$ and then for $1 \mathrm{~h}$ with either undiluted SBWMV CP monoclonal antiserum, undiluted SBWMV MP polyclonal antiserum (prepared by the Oklahoma State University Hybridoma Center), WSSMV polyclonal antiserum (obtained from Agdia, Elkhart, IN, U.S.A.) diluted either 1:50, 1:100, or 1:200, TMV antiserum (prepared by the Oklahoma State University Hybridoma Center) either undiluted or diluted 1:100, or buffer only. The slides were incubated for $1 \mathrm{~h}$ with secondary polyclonal fluorescein isothiocyanate(FITC)labeled rabbit or mouse antiserum (diluted 1:50).

\section{In situ RNA hybridization.}

Paraplast-embedded wheat roots were sectioned $(8.0 \mu \mathrm{m})$, and mounted on ProbeOn Plus slides (Fisher Biotechnology). Slides were incubated for 15 to $20 \mathrm{~min}$ at room temperature in $2 \times \mathrm{SSC}(1 \times \mathrm{SSC}$ is $0.15 \mathrm{M} \mathrm{NaCl}$ plus $0.015 \mathrm{M}$ sodium citrate) and then in proteinase $\mathrm{K}(1 \mu \mathrm{g}$ per $\mathrm{ml}$ of proteinase $\mathrm{K}$ dissolved in $100 \mathrm{mM}$ Tris- $\mathrm{HCl}, \mathrm{pH} 8.0,50 \mathrm{mM}$ EDTA) at $37^{\circ} \mathrm{C}$ for 15 to $20 \mathrm{~min}$. Slides were washed for $2 \mathrm{~min}$ at room temperature in PBS-glycine buffer $(130 \mathrm{mM} \mathrm{NaCl}, 7.0 \mathrm{mM}$ $\mathrm{Na}_{2} \mathrm{HPO}_{4}, 3.0 \mathrm{mM} \mathrm{NaH} \mathrm{PO}_{4}, 2.0 \mathrm{mg}$ per ml of glycine, $\mathrm{pH}$ 7.0) and twice with PBS buffer. Then, slides were incubated for $10 \mathrm{~min}$ at room temperature in $4 \%$ paraformaldehyde $(\mathrm{pH}$ 7.0) dissolved in PBS buffer. Slides were washed twice with PBS buffer for $5 \mathrm{~min}$ at room temperature, twice with $0.1 \mathrm{M}$ TEA buffer (1.492 $\mathrm{g}$ of triethanolamine per $100 \mathrm{ml}$ of water, $0.5 \mathrm{ml}$ of acetic anhydride) for $10 \mathrm{~min}$ at room temperature and then twice in PBS buffer for $5 \mathrm{~min}$ at room temperature.
Slides were incubated for $30 \mathrm{~min}$ at $37^{\circ} \mathrm{C}$ with prehybridization solution $(50 \%$ deionized formamide, $5 \%$ dextran sulfate, $1 \%$ blocking reagent [Roche Applied Sciences, Indianapolis, IN, U.S.A.], $500 \mu \mathrm{g} / \mathrm{ml}$ poly A, $300 \mathrm{mM} \mathrm{NaCl}, 10 \mathrm{mM}$ Tris$\mathrm{HCl}$ [pH 7.5], $1 \mathrm{mM}$ EDTA) and then overnight at $42^{\circ} \mathrm{C}$ with hybridization solution (prehybridization solution plus digoxigenin (DIG)-labeled RNA probe).

The plasmid p5114 is a pGEMT plasmid containing a cDNA copy of the 3' $100 \mathrm{nt}$ of SBWMV genome. Transcripts were prepared using ApaI-linearized p5114 plasmids, SP6 polymerase, and DIG-labeled UTP. Slides were washed twice with $0.2 \times$ SSC for $60 \mathrm{~min}$ at room temperature, twice with NTE buffer for $5 \mathrm{~min}$ at $37^{\circ} \mathrm{C}$, once in $0.2 \times \mathrm{SSC}$ for $60 \mathrm{~min}$ at $55^{\circ} \mathrm{C}$, and once in PBS for $5 \mathrm{~min}$ at room temperature.

For antibody labeling, slides were incubated for $45 \mathrm{~min}$ in $1 \%$ blocking reagent and then with $1 \%$ BSA fraction $\mathrm{V}$ (both

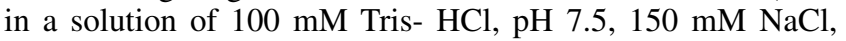
$0.3 \%$ Triton $\mathrm{X}-100)$. Slides were incubated for $2 \mathrm{~h}$ at room temperature with anti-DIG-labeled antiserum, (diluted 1:1,250 in $100 \mathrm{mM}$ Tris- $\mathrm{HCl}, \mathrm{pH} 7.5,150 \mathrm{mM} \mathrm{NaCl}, 0.3 \%$ Triton X100). Slides were washed twice for $15 \mathrm{~min}$ in a solution of 100 $\mathrm{mM}$ Tris- $\mathrm{HCl}(\mathrm{pH} 7.5)$ and $150 \mathrm{mM} \mathrm{NaCl}$, followed by a 10min wash in a solution of $100 \mathrm{mM}$ Tris- $\mathrm{HCl}$ (pH 9.5), $100 \mathrm{mM}$ $\mathrm{NaCl}$, and $50 \mathrm{mM} \mathrm{MgCl}_{2}$.

For developing the reaction, the substrate solution was prepared immediately before use by diluting $200 \mu \mathrm{m}$ of NBT/BCIP stock solution (DIG nucleic acid detection kit; Roche Applied Sciences) in $10 \mathrm{ml}$ of buffer 3 (100 mM Tris, $100 \mathrm{mM} \mathrm{NaCl}, 50 \mathrm{mM} \mathrm{MgCl}_{2}$ ). The slides were incubated with the color development solution in darkness for $2 \mathrm{~h}$ to 3 days at room temperature and then were rinsed in TE buffer (10.0 mM Tris-HCl, pH 8.2, $1.0 \mathrm{mM}$ EDTA). To minimize color loss, slides were dehydrated in a series of $25,50,75$, and $100 \%$ ethanol for a maximum of $5 \mathrm{~s}$ in each step. The slides were dipped in xylene. A drop of Permount and a coverslip were added to each slide prior to viewing under the light microscope.

\section{Microscopy.}

Individual plants were removed from Cone-tainers between 4 and 6 wpi and were washed using the root washing system. Washed roots were placed in distilled water in a $100-\mathrm{ml}$ beaker and were vacuum-infiltrated for $20 \mathrm{~min}$ to remove air from the interior of the roots. Small branch roots, located within $4 \mathrm{~cm}$ of the stem were cut into segments, mounted on slides, and examined with a Nikon Eclipse E600 microscope (Nikon Corp. Tokyo), using bright-field illumination to detect $P$. graminis. Cross sections of embedded wheat and barley roots were also examined by light microscopy following in situ hybridization. Images were recorded using an Optronics Magnafire digital camera (Goleta, CA, U.S.A.) and Image-Pro Plus software (Silver Spring, MD, U.S.A.). A Leica TCS SP2 (Leica Microsystems, Bannockburn, IL, U.S.A.) confocal imaging system was used to study FITC-labeling in root cross sections. The Leica TCS SP2 system was attached to a Leica DMRE microscope. Both microscopes were equipped with water immersion objectives. All figures were arranged using Adobe Photoshop software (Adobe Systems, Inc., Mountain View, CA, U.S.A.).

\section{Method for scoring roots for the presence of $\boldsymbol{P}$. graminis.}

Roots were harvested between 4 and 6 wpi. At 4 wpi, the average plant root mass was $30 \mathrm{~cm}$ in length and had an average wet weight of $4 \mathrm{~g}$. The large mass of each root system necessitated sampling few root segments for examination. Root segments from five to eight plants of each cultivar were observed for the presence of $P$. graminis sporosori. The numbers 
of plants positive for $P$ graminis relative to the total numbers of plant analyzed for each cultivar were determined. The numbers of sporosori were counted in 1-cm root segments, and six segments were analyzed per plant. Average numbers of sporosori observed in segments of infected roots were recorded for each cultivar in Tables 1 and 2.

\section{ACKNOWLEDGMENTS}

Financial support for this research was provided by Oklahoma State University Agricultural Experiment Station Project OKL-02371 and by grants provided by the United States Department of Agriculture National Research Initiative (2001-02723) and the Oklahoma Wheat Research Foundation (OKL-02371). We thank R. Hunger for providing a source of field material containing $P$. graminis. We thank S. Marek and M. Anderson for carefully reviewing the manuscript.

\section{LITERATURE CITED}

Adams, M. J. 1991. Transmission of plant viruses by fungi. Ann. Appl. Biol. 118:479-492.

Adams, M. J., and Swaby, A.G. 1988. Factors affecting the production and motility of zoospores of Polymyxa graminis and their transmission of Barley yellow mosaic virus (BaYMV). Ann. Appl. Biol. 112:69-78.

Adams, M. J., Swaby, A.G., and Macfarlane, I. 1986. The susceptibility of barley cultivars to Barley yellow mosaic virus (BaYMV) and its fungal vector, Polymyxa graminis. Ann. Appl. Biol. 109:561-572.

Adams, M. J., Jones, P., and Swaby, A. G. 1987. The effect of cultivar used as host for Polymyxa graminis on the multiplication and transmission of Barley yellow mosaic virus. Ann. Appl. Biol. 110:321-327.

Adams, M. J., Swaby, A. G., and Jones, P. 1988a. Confirmation of the transmission of Barley yellow mosaic virus (BaYMV) by the fungus Polymyxa graminis. Ann. Appl. Biol. 109:561-572.

An, H., Melcher, M., Doss, P., Payton, M., Guenzi, A. C., and VerchotLubicz, J. 2003. Evidence that the $37 \mathrm{kDa}$ protein of Soil-borne wheat mosaic virus is a virus movement protein. J. Gen. Virol. 84:3153-3163.
Brakke, M. K., and Langenberg, W. G. 1988. Experiences with Soil-borne wheat mosaic virus in North America and elsewhere. Pages 183-202 in: Developments in Applied Biology: Viruses with Fungal Vectors, Vol. 2. J. I. Cooper and M. J. C. Asher, eds. Association of Applied Biologists, Wellesbourne, England.

Campbell, R. N. 1988. Cultural characteristics and manipulative methods. Pages 153-164 in: Developments in Applied Biology: Viruses with Fungal Vectors, Vol 2. J. I. Cooper and M. J. C. Asher, eds. Association of Applied Biologists, Wellesbourne, England.

Driskel, B. A., Hunger, R. M., Payton, M. E., Verchot-Lubicz, J. 2002. Response of hard red winter wheat to Soilborne wheat mosaic virus using novel inoculation methods. Phytopathology 92:347-354.

Karling, J. S. 1968. The Plasmodiophorales. 2nd ed. Hafner Publishing Co., New York.

Kendall, T. L., and Lommel, S. A. 1988. Fungus-vectored viruses of wheat in Kansas. Pages 37-60 in: Developments in Applied Biology: Viruses with Fungal Vectors, Vol 2. J. I. Cooper and M. J. C. Asher, eds. Association of Applied Biologists, Wellesbourne, England.

Langenberg, W. G., and Giunchedi, L. 1982. Ultrastructure of fungal plant virus vectors Polymyxa graminis in Soilborne wheat mosaic virusinfected wheat and P. betae in Beet necrotic yellow vein virus-infected sugar beet. Phytopathology 72:1152-1158.

Ledingham, G. A. 1939. Studies on Polymyxa graminis, n. gen. n. sp., a plasmodiophoraceous root parasite of wheat. Can. J. Res. 17:38-51.

Littlefield, L. J., Whallon, J. H., Doss, P. J., and Hassan, Z. M. 1998. Postinfection development of Polymyxa graminis in roots of Triticum aestivum. Mycologia 90:869-882.

Melcher, U. 2000. The ' $30 \mathrm{~K}$ ' superfamily of viral movement proteins. J. Gen. Virol. 81:257-266.

Rao, A. S. 1968. Biology of Polymyxa graminis in relation to Soilborne wheat mosaic virus. Phytopathology 58:1516-1521.

Rao, A. S., and Brakke, M. K. 1969. Relation of Soilborne wheat mosaic virus and its fungal vector, Polymyxa graminis. Phytopathology 59:581587.

Verchot, J., Driskel, B.A., Zhu, Y., Hunger, R.M., and Littlefield, L. J. 2001. Soilborne wheat mosaic virus moves long distance through the xylem. Protoplasma 218:57-66.

Wiese, M. V. 1987. Diseases caused by viruses and virus like agents. Pages 66-87 in: Compendium of Wheat Diseases, 2nd ed. American Phytopathological Society Press, St. Paul, MN, U.S.A. 